\title{
フォームコアサンドイッチ梁の破壊勒性評価試験に関する解析*1 Analytical Study on the Fracture Toughness Characterization Tests of Foam Core Sandwich Specimens
}

\author{
横 関 智 弘*2 \\ Tomohiro YoKOzEKI
}

Key Words : Sandwich Structures, Foam Core, Fracture Toughness, Residual Stress, Crack Deflection

\begin{abstract}
This study shows two fundamental aspects related to fracture characterization of sandwich beams for aerospace application; 1) formulation of energy release rates associated with face sheet debonding or core cracking in sandwich beams with residual thermal stresses, and 2) crack kinking analysis of foam core sandwich beams. Energy release rates are formulated using the bi-layer shear deformable beam model with consideration of residual thermal stresses. This formulation is specifically applied to double cantilever beam (DCB), end notched flexure (ENF) and mixed mode bending (MMB) tests of sandwich structures. The derived analytical results are verified by comparison with finite element analysis. Next, the present formulation is applied to the prediction of crack kinking behaviors in foam core sandwich beams. It is demonstrated that overall crack kinking behaviors in foam core sandwich beams are well predicted using the present method. Some discussions on the fracture toughness measurement considering residual thermal stresses are also provided.
\end{abstract}

\section{1. 緒訔}

サンドイッチ構造は優れた曲げ特性を有することから, 航空機の 2 次構造, 船舶, 土木構造に多く適用されてきた. また，その高い比曲げ剛性や一体成形による製造性なども 考慮し, 航空機構造の主構造へも炭素繊維強化プラスチッ ク $(\mathrm{CFRP}) /$ フォームコア (発泡コア) を用いた軽量サン ドイッチ構造の適用も近年検討されている ${ }^{1)}$. サンドイッ チ構造を主構造へ適用する場合には, 表皮/コア間の剝離, コア内き裂，表皮内層間剝離などの損傷が懸念され2 4)，表 皮/コア間の剝離の進展を抑えるクラックストッパーの開発 などが進められている ${ }^{5 \sim 7)}$. フォームコアサンドイッチ構造 の破壊力学的評価や損傷許容性に関する検討の必要性が高 まっている状況である.

サンドイッチ構造を航空機の主構造で使用する場合には, 高温での優れた機械的特性が求められるため，通常は，高 温硬化型の樹脂を使用した，接着もしくは一体成形による 構造となる。そのため, 常温もしくは低温環境で使用され るサンドイッチ構造内は, 主にコアと表皮の熱膨張係数の 差に起因する熱残留応力が誘発されることとなる。この熱 残留ひずみ（もしくは初期ひずみ）は，表皮/コア間の剥離 に関する破壊力学的評価を実施する場合にも, 破壊勒性值 の算出過程で考慮すべきものである. 特に, $\mathrm{CFRP} /$ フォー ムコアのサンドイッチ構造の場合は, 表皮とコアの熱膨張

\footnotetext{
*1 (C) 2011 日本航空宇宙学会

平成 22 年 10 月 4 日原稿受付

*2 東京大学大学院工学系研究科航空宇宙工学専攻
}

係数差が大きく, また, 厚い構造となることから, 熱残留 応力の破壊力学的パラメーター（エネルギー解放率など） への寄与も高いため, 破壊勒性值評価において熱残留応力 の影響は無視することができない.

サンドイッチ構造の破壊力学的試験としては, 通常の複合 材料における試験と同様に, 表皮/コア間の剝離き裂に関し て, DCB (Double cantilever beam) 試験8, 9), ENF (End notched flexure) 試験10), MMB (Mixed mode bending) 試験11) などが提案されている，通常は，梁モデルなどを用 いた解析的な式を用いるか, 実験コンプライアンス法など により破壊勒性值を算出するが, 上述した熱残留応力の影 響については考慮されていない. 有限要素解析などの数值 計算により, 力学的荷重及び熱応力を考慮した破壊勒性值 評価も可能であるが，より簡易な手法の開発も有用である.

また，フォームコアサンドイッチ構造の破壊力学的試験 において，き裂偏向が問題となる場合も多い9)。例えば，表 皮/コア間の剝離進展に関する評価を行うために表皮/コア 間に初期き裂を導入し，き裂進展試験を実施しても，試験 中にき裂がコア内もしくは表皮内に偏向し, 表皮/コア間の 破壊勒性值を取得できなくなる場合もある。き裂の偏向は, 材料の組み合わせや形状, 荷重条件によっても変わるため, 求めたい特性を取得可能な破壊力学的試験用の試験片設計 が事前に可能となれば，効率的な評価試験・開発にとって 大変有用であると考えられる，

本研究は, 上述の背景から, i) 熱残留応力を考慮したサ ンドイッチ構造用破壊勒性試験に関するエネルギー解放率 (破壊勒性值算出のための式), ii) フォームコアサンドイッ 
チ構造のき裂偏向に関する解析, について, その解析手法 を提示する。サンドイッチ構造の破壊勒性評価試験として, 特にDCB 試験, ENF 試験, MMB 試験について提案する とともに, 熱残留応力による, 破壊勒性值の評価值やき裂 偏向への影響について議論する.

\section{2. エネルギー解放率}

本研究で想定する破壊力学的評価試験用のサンドイッチ 梁を第 1 図 (a) に示す. 表皮材及びコア材ともに構造内で 一定の厚み・幅を有するものとし, き裂（長さ $a$ ）は, 上 側の表皮/コア間の界面から $h_{c p}$ だけ平行に離れているも のとする. 尚, 熱残留応力は樹脂の硬化過程や周囲環境に 大きく依存し, 粘弾性効果もあり, 簡単には推定できない. 本研究では, 熱ひずみの基準温度（応力フリー温度）が既 知（例えば, 非対称梁の曲げ変形の測定などからマクロに は見かけ值が推定可能である）とした場合に，熱ひずみを 考慮した弾性解析による定式化を行う。 その際, 以前の研 究12)における, 異種材の界面き裂に関するエネルギー解放 率の定式化を利用する。以下には, 利用する 2 層梁モデル とエネルギー解放率の導出について簡単にまとめ, DCB 試 験, $\mathrm{ENF}$ 試験, $\mathrm{MMB}$ 試験におけるエネルギー解放率に ついて順に説明する.

2.1 き裂先端力とエネルギー解放率 ${ }^{12}$ ) 第 1 図 (a)のき 裂を有するサンドイッチ梁を, 第 1 図 (b) に示すように, き 裂面を境として，上下の 2 層の sublaminate（上側を添え字 1 ，下側を添え字 2 で表す）とみなしてモデル化する. クラッ ク先端位置及び各 sublaminate の中央面を各 sublaminate の局所座標軸の基準として設定すると, 各 sublaminate 内 の変位分布 $(U, W)$ は各中央面での值 $(u, \phi, w)$ を用いて 以下のように表される。

$$
\begin{aligned}
& U_{i}\left(x_{i}, z_{i}\right)=u_{i}(x)+z_{i} \phi_{i}(x) \\
& W_{i}\left(x_{i}, z_{i}\right)=w_{i}(x)
\end{aligned}
$$

ここで, 添え字 $i$ は各 sublaminate を示す. また, 各 sublaminate の構成方程式は初期ひずみを考慮して以下のよう

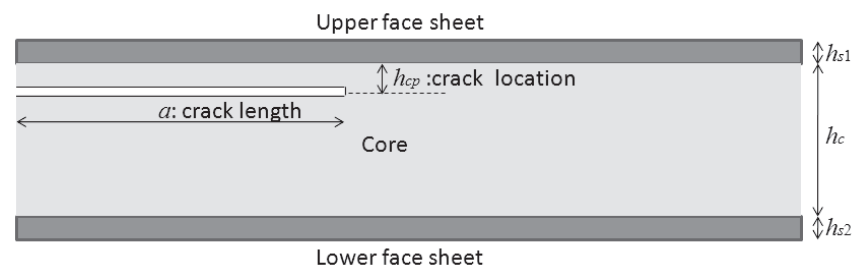

(a)き裂を有するサンドイッチ梁

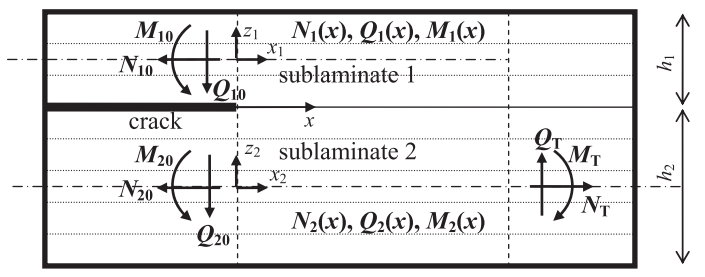

(b) 2 層はりモデル

第1図き裂を有するサンドイッチ梁とそのモデル化
に表される。

$$
\begin{aligned}
& \left\{\begin{array}{l}
N_{i} \\
M_{i}
\end{array}\right\}=\left[\begin{array}{ll}
A_{i} & B_{i} \\
B_{i} & D_{i}
\end{array}\right]\left\{\begin{array}{l}
\varepsilon_{i} \\
\kappa_{i}
\end{array}\right\}-\left\{\begin{array}{l}
N_{T i} \\
M_{T i}
\end{array}\right\} \\
& Q_{i}=\kappa C_{i} \gamma_{i}
\end{aligned}
$$

(2) 式の第 1 式については,

$$
\left\{\begin{array}{c}
\varepsilon_{i} \\
\kappa_{i}
\end{array}\right\}=\left[\begin{array}{ll}
a_{i} & b_{i} \\
b_{i} & d_{i}
\end{array}\right]\left\{\begin{array}{l}
N_{i} \\
M_{i}
\end{array}\right\}+\left\{\begin{array}{l}
\alpha_{N i} \\
\alpha_{M i}
\end{array}\right\}
$$

と書くこともできる。ただし，

$\varepsilon_{i}=\frac{\mathrm{d} u_{i}}{\mathrm{~d} x}, \quad \kappa_{i}=\frac{\mathrm{d} \phi_{i}}{\mathrm{~d} x}, \quad \gamma_{i}=\phi_{i}+\frac{\mathrm{d} w_{i}}{\mathrm{~d} x}$

$A_{i}=B \int E_{i} \mathrm{~d} z_{i}, \quad B_{i}=B \int E_{i} z_{i} \mathrm{~d} z_{i}$

$D_{i}=B \int E_{i} z_{i}^{2} \mathrm{~d} z_{i}, \quad C_{i}=B \int G_{i} \mathrm{~d} z_{i}$

$N_{T i}=B \int E_{i} \alpha_{i} \Delta T \mathrm{~d} z_{i}, \quad M_{T i}=B \int E_{i} \alpha_{i} \Delta T z_{i} \mathrm{~d} z_{i}$

$a_{i}=\frac{D_{i}}{A_{i} D_{i}-B_{i}{ }^{2}}, \quad b_{i}=\frac{-B_{i}}{A_{i} D_{i}-B_{i}{ }^{2}}, \quad d_{i}=\frac{A_{i}}{A_{i} D_{i}-B_{i}{ }^{2}}$

$\alpha_{N i}=\frac{D_{i} N_{T i}-B_{i} M_{T i}}{A_{i} D_{i}-B_{i}{ }^{2}}, \quad \alpha_{M i}=\frac{A_{i} M_{T i}-B_{i} N_{T i}}{A_{i} D_{i}-B_{i}{ }^{2}}$

であり， $B$ は梁の幅， $E$ は面内ヤング率， $G$ はせん断剛 性, $\alpha$ は熱膨張係数, $\kappa$ はせん断係数, $\Delta T$ は温度変化（使 用温度と応力フリー温度の差) である.

クラック先端からき裂のない側の領域（全体長さに比べ 微小領域)について, 釣り合い式や変位の連続条件を考慮す ることで12), 上側の sublaminateの応力分布を導出すると,

$$
\begin{aligned}
& N_{1}(x)=c_{0} e^{-\lambda x}+N_{1 P} \\
& M_{1}(x)=\frac{\eta}{\xi} c_{0} e^{-\lambda x}+M_{1 P} \\
& Q_{1}(x)=-\left(\frac{\eta}{\xi}+\frac{h_{1}}{2}\right) c_{0} \lambda e^{-\lambda x}+Q_{1 P}
\end{aligned}
$$

となる。ただし，

$$
\begin{aligned}
N_{1 P}= & \frac{F}{\beta} \\
M_{1 P}= & \frac{1}{\xi}\left\{\eta N_{1 P}-\left(a_{2}+\frac{h_{2}}{2} b_{2}\right) N_{T}-\left(b_{2}+\frac{h_{2}}{2} d_{2}\right) M_{T}\right. \\
& \left.-\left(\alpha_{N 2}-\alpha_{N 1}\right)+\frac{h_{1}}{2} \alpha_{M 1}+\frac{h_{2}}{2} \alpha_{M 2}\right\} \\
Q_{1 P}= & \frac{Q_{T}}{\xi}\left\{\frac{\left(h_{1} \xi+2 \eta\right)\left(b_{2} d_{1}-b_{1} d_{2}+\frac{h_{1}+h_{2}}{2} d_{1} d_{2}\right)}{2 \beta}\right. \\
& \left.-\left(b_{2}+\frac{h_{2}}{2} d_{2}\right)\right\}
\end{aligned}
$$




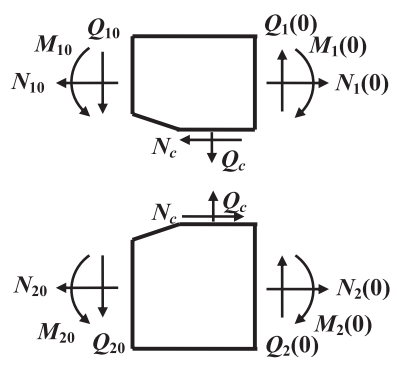

第 2 図き裂先端の力

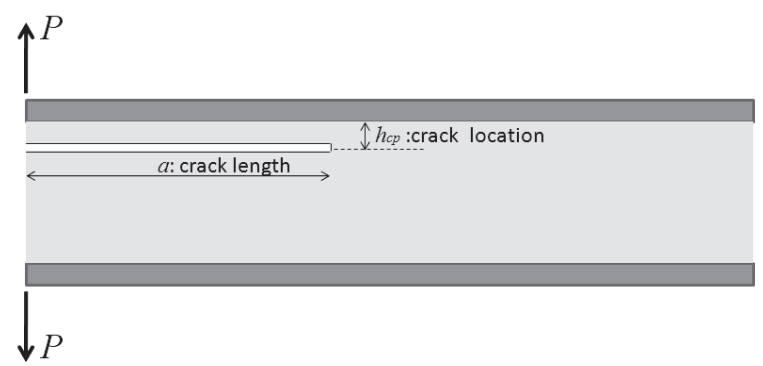

第3図 DCB 試験片
であり，

$$
\begin{aligned}
\beta= & \left(b_{1}+b_{2}+\frac{h_{1}+h_{2}}{2} d_{2}\right) \xi+\left(d_{1}+d_{2}\right) \eta \\
\chi= & \left(\frac{1}{\kappa C_{1}}+\frac{1}{\kappa C_{2}}\right)\left(\eta+\frac{h_{1}}{2} \xi\right) \\
F= & \left\{a_{2}\left(d_{1}+d_{2}\right)-b_{2}\left(b_{1}+b_{2}-\frac{h_{1}+h_{2}}{2} d_{1}\right)\right\} N_{T} \\
& +\left\{b_{2}\left(d_{1}+d_{2}\right)-d_{2}\left(b_{1}+b_{2}-\frac{h_{1}+h_{2}}{2} d_{1}\right)\right\} M_{T} \\
& +\left(d_{1}+d_{2}\right)\left(\alpha_{N 2}-\alpha_{N 1}\right)+\left(b_{1}+b_{2}+\frac{h_{1}+h_{2}}{2} d_{2}\right) \alpha_{M 1} \\
& +\left(-b_{1}-b_{2}+\frac{h_{1}+h_{2}}{2} d_{1}\right) \alpha_{M 2} \\
\eta= & a_{1}+a_{2}-\frac{h_{1}}{2} b_{1}+\left(\frac{h_{1}}{2}+h_{2}\right) b_{2}+\frac{h_{2}\left(h_{1}+h_{2}\right)}{4} d_{2} \\
\xi= & -b_{1}-b_{2}+\frac{h_{1}}{2} d_{1}-\frac{h_{2}}{2} d_{2} \\
\lambda= & \sqrt{\frac{\beta}{\chi}}
\end{aligned}
$$

と与えられる．尚， $c_{0}$ は後述のように決定される.

き裂先端の力の釣り合いを考えるとクラック先端に自己 平衡系の集中力が各 sublaminate に作用しているはずであ り，第 2 図のようなき裂先端での釣り合いを考え，き裂先 端集中力 $\left(N_{c}, Q_{c}\right)$ を求める. sublaminate 1 に関する力の 釣り合いから，

$$
\begin{aligned}
& N_{10}=-N_{c}+N_{1}(0) \\
& Q_{10}=-Q_{c}+Q_{1}(0) \\
& M_{10}=\frac{h_{1}}{2} N_{c}+M_{1}(0)
\end{aligned}
$$

が得られ，(7) 式を用いてき裂先端 $(x=0)$ での值を代入
すると, $N_{c}, Q_{c}, c_{0}$ が以下のように決定される.

$$
\begin{aligned}
& N_{c}=\frac{2(M \xi-N \eta)}{h_{1} \xi+2 \eta} \\
& Q_{c}=-Q-\lambda\left(M+\frac{h_{1}}{2} N\right) \\
& c_{0}=\frac{\xi\left(2 M+h_{1} N\right)}{h_{1} \xi+2 \eta}
\end{aligned}
$$

ただし，

$$
\begin{aligned}
& N=N_{10}-N_{1 P}, \quad Q=Q_{10}-Q_{1 P} \\
& M=M_{10}-M_{1 P}
\end{aligned}
$$

である。このき裂先端集中力を用いて, Irwinの方法（き 裂閉口法）によりエネルギー解放率を求めると,

$$
\begin{aligned}
& G_{\mathrm{I}}=\frac{1}{2 B}\left(\frac{1}{\kappa C_{1}}+\frac{1}{\kappa C_{2}}\right) Q_{c}{ }^{2} \\
& G_{\mathrm{II}}=\frac{1}{2 B}\left(\eta+\frac{h_{1}}{2} \xi\right) N_{c}^{2} \\
& G_{\text {total }}=G_{\mathrm{I}}+G_{\mathrm{II}}
\end{aligned}
$$

となる. 2 層 Timoshenko 梁の変形の仮定においては, (13) 式で各モードのエネルギー解放率が求められる. 各試験条 件における荷重条件や境界条件が与えられるとき裂端近傍 の荷重条件が得られ（第 1 図 (b) の $N_{10}, Q_{10}, M_{10}, N_{T}$, $Q_{T}$, 及び $\left.M_{T}\right)$, エネルギー解放率を算出することができ る. 次節から具体的な試験条件におけるエネルギー解放率 の定式化を示す。

$2.2 \mathrm{DCB}$ 試験の場合 一般的な DCB 試験片の概観を 第 3 図に示す，荷重条件を考慮すると，き裂端近傍の荷重 条件は,

$$
\begin{array}{ll}
N_{10}=0, & Q_{10}=-P, \quad M_{10}=-P a \\
N_{T}=0, & Q_{T}=0, \quad M_{T}=0
\end{array}
$$

で与えられる。これを $(8)$ 式に代入すると,

$$
\begin{aligned}
& N_{1 p}=\frac{\left(d_{1}+d_{2}\right)\left(\alpha_{N 2}-\alpha_{N 1}\right)+\left(b_{1}+b_{2}+\frac{h_{1}+h_{2}}{2} d_{2}\right) \alpha_{M 1}+\left(-b_{1}-b_{2}+\frac{h_{1}+h_{2}}{2} d_{1}\right) \alpha_{M 2}}{\left(d_{1}+d_{2}\right) \eta+\left(b_{1}+b_{2}+\frac{h_{1}+h_{2}}{2} d_{2}\right) \xi} \\
& M_{1 p}=\frac{1}{\xi}\left\{\eta N_{1 P}-\left(\alpha_{N 2}-\alpha_{N 1}\right)+\frac{h_{1}}{2} \alpha_{M 1}+\frac{h_{2}}{2} \alpha_{M 2}\right\} \\
& Q_{1 p}=0
\end{aligned}
$$




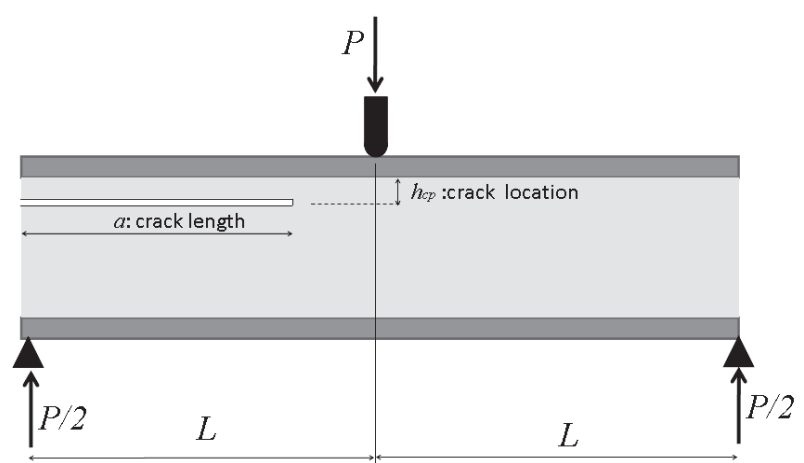

第 4 図 ENF 試験片

が得られ，(14) 式及び (15) 式を (12) 式を用いて (11) 式に 代入することで，き裂先端力 $\left(N_{c}, Q_{c}\right)$ が求まる.さらに (13) 式を用いることで，エネルギー解放率を計算すること ができる.

$2.3 \mathrm{ENF}$ 試験の場合 一般的な ENF 試験片について, 第 4 図に示す. $\mathrm{ENF}$ 試験の場合は, 通常はき裂部の上下 アームの接触が生じることから, き裂面に接触荷重が作用 するため, 上述モデルにおける荷重条件推定が困難である. そこで，熱残留変形により上下アームが開口し，試験中に 接触が起こらない場合と, 第 5 図に示すように, 熱残留変

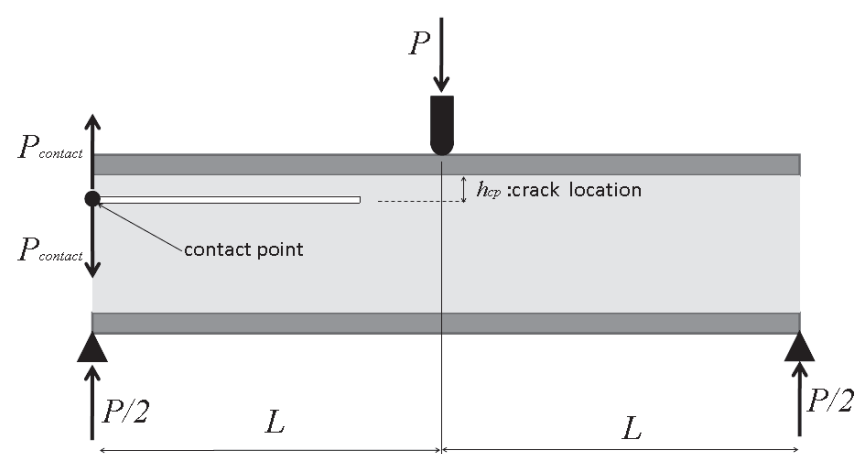

第 5 図 $\mathrm{ENF}$ 試験片：左端でき裂アーム部同士の接触が生じる場合

形（き裂部の曲げ変形）により接触が下支持部と同じ位置 の 1 点のみで生じる場合について, 摩擦は無視して以下に 定式化する。それ以外の場合は適用困難であり，また，上 述の特殊状況が当てはまるかは詳細検討が必要である。

上下アームの接触が生じない場合は, き裂近傍の荷重条件は

$$
\begin{array}{ll}
N_{10}=0, & Q_{10}=0, \quad M_{10}=0 \\
N_{T}=0, & Q_{T}=-\frac{P}{2},
\end{array}
$$

となる。したがって，(8) 式は，

$$
\begin{aligned}
& N_{1 p}=-\frac{\left(b_{2} d_{1}-b_{1} d_{2}+\frac{h_{1}+h_{2}}{2} d_{1} d_{2}\right)}{\left(d_{1}+d_{2}\right) \eta+\left(b_{1}+b_{2}+\frac{h_{1}+h_{2}}{2} d_{2}\right)} \frac{P}{2} a \\
& +\frac{\left(d_{1}+d_{2}\right)\left(\alpha_{N 2}-\alpha_{N 1}\right)+\left(b_{1}+b_{2}+\frac{h_{1}+h_{2}}{2} d_{2}\right) \alpha_{M 1}+\left(-b_{1}-b_{2}+\frac{h_{1}+h_{2}}{2} d_{1}\right) \alpha_{M 2}}{\left(d_{1}+d_{2}\right) \eta+\left(b_{1}+b_{2}+\frac{h_{1}+h_{2}}{2} d_{2}\right) \xi} \\
& M_{1 p}=\frac{1}{\xi}\left\{\eta N_{1 P}+\left(b_{2}+\frac{h_{2}}{2} d_{2}\right) \frac{P}{2} a-\left(\alpha_{N 2}-\alpha_{N 1}\right)+\frac{h_{1}}{2} \alpha_{M 1}+\frac{h_{2}}{2} \alpha_{M 2}\right\} \\
& Q_{1 p}=-\frac{P}{2}\left\{\left(\frac{\eta}{\xi}+\frac{h_{1}}{2}\right) \frac{d_{2} \xi+\left(d_{1}+d_{2}\right)\left(b_{2}+\frac{h_{2}}{2} d_{2}\right)}{\left(d_{1}+d_{2}\right) \eta+\left(b_{1}+b_{2}+\frac{h_{1}+h_{2}}{2} d_{2}\right) \xi}-\frac{b_{2}+\frac{h_{2}}{2} d_{2}}{\xi}\right\}
\end{aligned}
$$

となる。(16) 式及び (17) 式を (12) 式を用いて (11) 式に代 入することで，き裂先端力が求まり，さらに(13) 式を用い ることで，エネルギー解放率を計算することができる.

一方で，第 5 図のように，熱残留変形によりき裂アーム 部が曲がり, 接触が左端の 1 点でのみ生じる場合について は，接触点での上下のアームのたわみが等しくなる条件か ら, 生じているべき接触力 $\left(P_{\text {contact }}\right)$ を求めると,

$$
\begin{aligned}
& P_{\text {contact }}=-\frac{3\left(\alpha_{M 1}-\alpha_{M 2}\right)}{2 a\left(d_{1}+d_{2}\right)}+\zeta \frac{P}{2} \\
& \zeta=\frac{\frac{a^{3}}{3} d_{2}+\frac{a}{\kappa C_{2}}}{\frac{a^{3}}{3}\left(d_{1}+d_{2}\right)+a\left(\frac{1}{\kappa C_{1}}+\frac{1}{\kappa C_{2}}\right)}
\end{aligned}
$$

となり，このときのき裂近傍の荷重条件は,

$N_{10}=0, \quad Q_{10}=-P_{\text {contact }}, \quad M_{10}=-P_{\text {contact }} a$

$N_{T}=0, \quad Q_{T}=-\frac{P}{2}, \quad M_{T}=-\frac{P}{2} a$

で与えられる。このとき，(8) 式は (17) 式で与えられ，(19) 式及び (17) 式を (12) 式を用いて (11) 式に代入することで, き裂先端力が求まり，上述と同じようにエネルギー解放率 が得られる。

$2.4 \mathrm{MMB}$ 試験の場合 一般的な MMB 試験片につい て，第 6 図に示す. MMB 試験の荷重条件から,

$$
P_{e}=P \frac{c}{L}, \quad P_{c}=P \frac{c+L}{L}
$$


第 1 表 解析で用いた材料特性

\begin{tabular}{lcccccc}
\hline & $\begin{array}{c}E_{x} \\
{[\mathrm{GPa}]}\end{array}$ & $\begin{array}{c}E_{z} \\
{[\mathrm{GPa}]}\end{array}$ & $\begin{array}{c}G_{x z} \\
{[\mathrm{GPa}]}\end{array}$ & $\nu_{x z}$ & $\alpha_{x}\left[10^{-6} / \mathrm{K}\right]$ & $\alpha_{z}\left[10^{-6} / \mathrm{K}\right]$ \\
\hline Face sheet & 58.5 & 10.1 & 3.64 & 0.37 & 0.91 & 32.7 \\
Core (isotropic) & \multicolumn{2}{c}{0.24} & 0.086 & 0.40 & & 40 \\
\hline
\end{tabular}

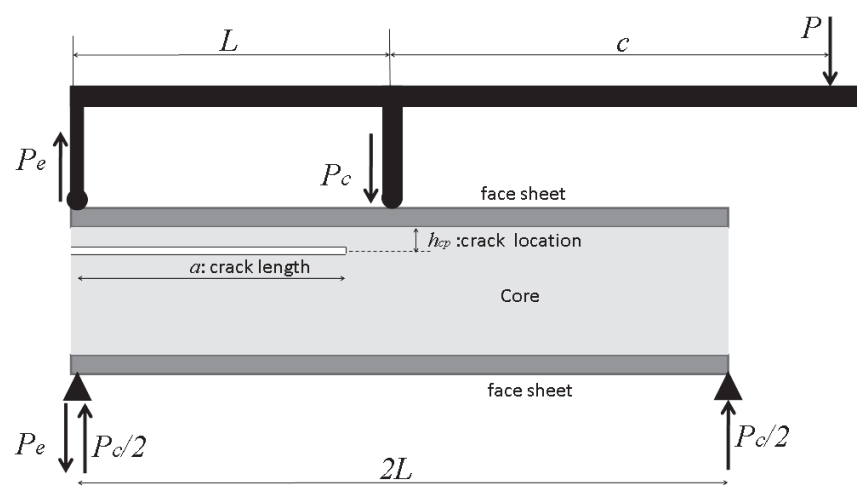

第 6 図 MMB 試験片

と与えられ，これらをき裂先端近傍の荷重条件に書き換え ると，

$$
\begin{array}{lll}
N_{10}=0, & Q_{10}=-P_{e}, & M_{10}=-P_{e} a \\
N_{T}=0, & Q_{T}=-\frac{P_{c}}{2}, & M_{T}=-\frac{P_{c}}{2} a
\end{array}
$$

となる.この荷重条件は 1 点での接触を仮定した場合の ENF 試験と同様となり，(19) 式の $P_{\text {contact }}$ を $P_{e}$ と, (17), (19) 式の $P$ を $P_{c}$ とそれぞれ置き換えればよく, (11) (13) 式 よりエネルギー解放率を求めることができる.

2.5 FEM 解析との比較と破壊勒性試験に関する考察 本研究で示したエネルギー解放率については, 以前の研究で FEM解析と比較することにより, 力学的荷重のみの場合, 及 び力学的荷重及び熱荷重 $(\Delta T)$ が作用する場合について, 妥 当性を確認している12). しかしながら, 以前の検証では, 板 厚の薄い接着構造について確認しているだけであり, ここで はフォームコアサンドイッチ構造について検証を行った。

$\mathrm{CFRP}$ (厚さ $2 \mathrm{~mm}$ ) /フォームコア (厚さ $25 \mathrm{~mm}$ )/CFRP (厚さ $2 \mathrm{~mm}$ ) のサンドイッチ梁（全体長さ $200 \mathrm{~mm}$, 幅 $30 \mathrm{~mm}$ ) を考え, 長さ $80 \mathrm{~mm}$ のき裂が上面 CFRP とフォー ムコアの界面に存在する場合に, DCB 試験を想定した荷重 を作用させエネルギー解放率を FEM と本解析にて比較し た. 熱残留ひずみを考虑する際は，温度変化として $-100[\mathrm{~K}]$ を与えた。用いた材料特性を第 1 表にまとめる.

与えたせん断荷重とエネルギー解放率との関係を第 7 図 に示す. FEM と本解析は, 力学的荷重のみの場合及び力学 的荷重及び熱荷重の場合ともによい一致を示しており, 本 解析のサンドイッチ構造への適用の妥当性も検証できた. また，熱残留ひずみを考慮することで，エネルギー解放率 が変化していることも確認でき, 航空機用途のサンドイッ チ構造では熱荷重の考慮が破壊勒性試験に扔いても重要で あることがわかる。また，第 7 図の範囲では，熱残留ひず みを考慮することで, 考慮しない場合に比ベエネルギー解

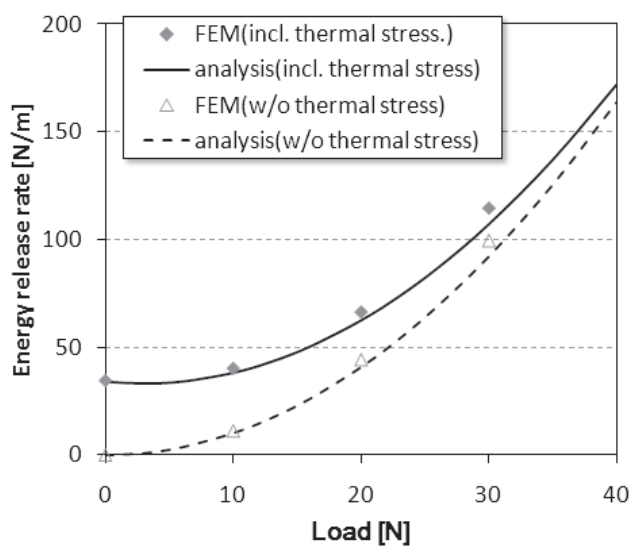

第 7 図 DCB 試験における荷重とエネルギー解放率の関係

放率は高くなっている（破壞勒性值算出の際に, 熱残留ひ ずみを考慮しないことで低めの破壊勒性値を算出してしま う）が, 試験片形状や荷重状態によっては, 熱残留ひずみ を考慮しないことで, 算出する破壊勒性值を過大評価して しまう場合もある。午のため, 破壊勒性值算出の際に熱残 留ひずみを考慮することは非常に重要である.

本解析モデルはせん断変形の影響は考慮しているものの, 厚み方向の伸び変形を考慮していない，コアが柔軟で厚い サンドイッチ構造の場合は, 厚み方向の変形が顕著となり, 本解析を適用するとエネルギー解放率に誤差を生じる（低 めのエネルギー解放率を与える) ことになると考えられる. これは第 7 図に执いても FEM との差が認識でき, 例えばコ アの弾性率が低くなるとこの差は顕著になってくる。しかし ながら, この誤差は, 力学的荷重に扔けるエネルギー解放率 算出時に起因するものであり, 力学的荷重のみの場合の工 ネルギー解放率 $(G=G(P, \Delta T=0))$ と力学的荷重及び熱 荷重が作用する場合のエネルギー解放率 $\left(G^{\prime}=G(P, \Delta T)\right)$ との差 $\left(\Delta G=G^{\prime}-G\right)$ は FEM と本解析で非常によく一 致し, 柔軟かつ厚いコア構造の場合でもよく一致する.

したがって，フォームコアサンドイッチ構造での破壊勒 性試験に扔いて, 熱残留応力を考慮して破壊勒性值を算出 する方法として,

1）低めの破壊勒性值を算出する可能性があることを認め た上で本論文の式などを用いて，熱残留ひずみを考慮した 破壊勒性值算出を行う

2）力学的荷重におけるエネルギー解放率については，実 験コンプライアンス法や従来の詳細解析モデル（弾性支持 モデル8,11) など）を使用して求め, 熱残留応力による影響 (エネルギー解放率差 : $\Delta G$ ) のみを本手法などにより後で 補正する

のいずれかを推奨する。手間をかけてもよいのであれば, 
個々のデータに対して FEM 等の詳細数值計算により熱残 留ひずみを考慮した破壊勒性值算出を行ってもよい. 以上 により，フォームコアサンドイッチ構造の破壊勒性試験の 際に，熱残留応力の影響を修正した破壊勒性值算出が可能 であると考えられる。

\section{3. き裂偏向解析}

フォームコアサンドイッチ構造中のき裂は第 8 図のよう にき裂面に沿って進展せず, 破壊勒性試験中に, 偏向角 $\Omega$ の方向に進展する可能性がある.ここでは, 2 節で導出し た各モードのエネルギー解放率を用い, フォームコア内に き裂がある場合のき裂偏向角に関する解析手法を示す。き 裂が表皮/コア界面にある場合や界面近傍にある場合は，き 裂の振動特異性を考慮した解析が必要であるが, ここでは, フォームコアを均質等方性材とみなし, 均質等方性材中の き裂として扱えるものと仮定する.

均質等方性材中の各モードのエネルギー解放率と応力拡 大係数の関係は,

$$
\begin{aligned}
& K_{\mathrm{I}}= \begin{cases}\sqrt{E_{c} G_{\mathrm{I}}} & \left(Q_{c}>0\right) \\
-\sqrt{E_{c} G_{\mathrm{I}}} & \left(Q_{c}<0\right)\end{cases} \\
& K_{\mathrm{II}}= \begin{cases}\sqrt{E_{c} G_{\mathrm{II}}} & \left(N_{c}>0\right) \\
-\sqrt{E_{c} G_{\mathrm{II}}} & \left(N_{c}<0\right)\end{cases}
\end{aligned}
$$

で与えられる。 ここで, 本解析モデル中のクラック先端力 の正負により, 応力拡大係数の正負も (22) 式のように決定

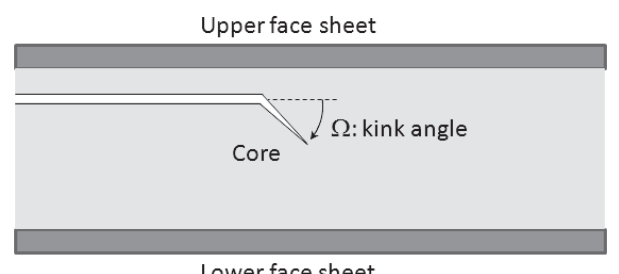

第8図 フォームコアサンドイッチ梁のき裂偏向
される，尚，負の $K_{\mathrm{I}}$ はき裂部の貫入を意味しているが, 本研究の後述の例では, 常に正である.

Erdogan and $\mathrm{Sih}^{13)}$ は均質等方性材料中のき裂進展方向 は周方向引張応力が最大となる向きになることを示してお り, 本研究でも, き裂進展方向について, この条件を適用 すると，偏向角 $\Omega$ は以下で与えられる。

$$
\Omega=2 \tan ^{-1}\left[\frac{\sqrt{1+8\left(\frac{K_{\mathrm{II}}}{K_{\mathrm{I}}}\right)^{2}}-1}{4\left(\frac{K_{\mathrm{II}}}{K_{\mathrm{I}}}\right)}\right]
$$

したがって，き裂が上側表皮/コア間の界面から $h_{c p}$ だけ 離れた位置にあるときに，2節で示したモード別のエネル ギー解放率を算出し，(22), (23) 式を用いてき裂の偏向角 を予測することができる.

本手法の妥当性を検証するため, Carlsson ら ${ }^{9)}$ のフォー ムコアサンドイッチ梁を用いた DCB 試験における，き裂 偏向角に関する実験データとの比較を行った．材料特性及 び試験片形状は文献 9) を参照し, 実験では常温にて硬化及 び試験を行っていたため, 熱残留ひずみは考慮せず, 解析 を行った，文献 9) を参考に，本解析で用いた材料特性を第 2 表にまとめる。第 3 表にき裂偏向角の比較を示すが, 概 ねよい一致が得られた。尚, 表中の $\mathrm{T} 1$ 試験片はき裂が上 側の表皮/コア界面近くに位置し, 負の偏向角を予測してい るが, き裂が表皮を貫かないとすると, 偏向しない実験結 果と一致する.

この解析法を利用し，第 3 表中の I45 及び $\mathrm{T} 1$ 試験片の 形状を用いて, き裂位置 $\left(h_{c p}\right)$ を変化させて, き裂偏向角 をプロットしたものを第 9 図に示す. I45 試験片（第 9 図 (a)）では，き裂位置がコアの上半分にある場合は正の偏向 角が予測され, 下半分にある場合は負の偏向角となる。こ れは，き裂位置がコアの上部にある場合は，下向きにき裂 が偏向し，き裂がコア下部にある場合は, 上向きに偏向す

第 2 表 き裂偏向解析で用いた材料特性

\begin{tabular}{lcccccc}
\hline & $\begin{array}{c}E_{x} \\
{[\mathrm{GPa}]}\end{array}$ & $\begin{array}{c}E_{z} \\
{[\mathrm{GPa}]}\end{array}$ & $\begin{array}{c}G_{x z} \\
{[\mathrm{GPa}]}\end{array}$ & $\nu_{x z}$ & $\alpha_{x}\left[10^{-6} / \mathrm{K}\right]$ & $\alpha_{z}\left[10^{-6} / \mathrm{K}\right]$ \\
\hline GFRP & 27.6 & $10.0^{*}$ & $3.6^{*}$ & $0.35^{*}$ & $9.0^{*}$ & $20^{*}$ \\
CFRP & 82.7 & $10.0^{*}$ & $3.6^{*}$ & $0.35^{*}$ & $0.9^{*}$ & $20^{*}$ \\
PVC core & 0.105 & 0.04 & 0.32 & & $40^{*}$ & \\
\hline
\end{tabular}

\begin{tabular}{|c|c|c|c|c|c|c|c|c|}
\hline \multirow[b]{2}{*}{ Specimen } & \multicolumn{2}{|c|}{ Upper face } & \multicolumn{2}{|c|}{ Lower face } & \multirow{2}{*}{$\begin{array}{c}\text { Core } \\
h_{c} \\
{[\mathrm{~mm}]}\end{array}$} & \multirow{2}{*}{$\begin{array}{c}\text { Crack } \\
\text { location } \\
h_{c p}[\mathrm{~mm}]\end{array}$} & \multicolumn{2}{|c|}{ Kink angle $\left[{ }^{\circ}\right]$} \\
\hline & Material & $\begin{array}{c}h_{s 1} \\
{[\mathrm{~mm}]}\end{array}$ & Material & $\begin{array}{c}h_{s 2} \\
{[\mathrm{~mm}]}\end{array}$ & & & Exp. & Pred. \\
\hline I30 & GF & 4.04 & GF & 4.04 & 14.2 & 7.6 & 0 & -3.0 \\
\hline $\mathrm{I} 40$ & GF & 2.43 & GF & 2.43 & 15.6 & 0.7 & 9 & 13.8 \\
\hline $\mathrm{I} 41$ & GF & 2.41 & GF & 2.41 & 17.6 & 8.12 & -14 & -3.8 \\
\hline I 43 & GF & 2.37 & $\mathrm{CF}$ & 3.89 & 17.2 & 8.9 & -60 & -51.3 \\
\hline I45 & $\mathrm{CF}$ & 3.95 & $\mathrm{CF}$ & 3.95 & 17.6 & 1.2 & 22 & 35.1 \\
\hline $\mathrm{I} 50$ & GF & 2.41 & $\mathrm{CF}$ & 3.98 & 17.3 & 16.9 & -78 & -49.9 \\
\hline $\mathrm{T} 1$ & GF & 2.41 & GF & 2.41 & 37.9 & 0.8 & 0 & -24.2 \\
\hline
\end{tabular}

*assumed values.

第 3 表 フォームコアサンドイッチ梁におけるき裂偏向角の比較（実験データは文献 9) を参照）

GF: GFRP, CF: CFRP. 


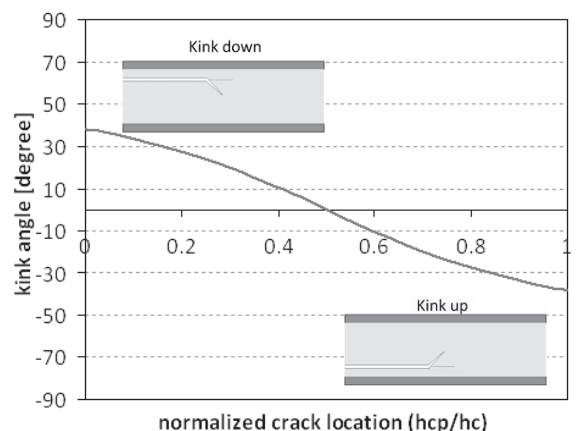

(a) I45 試験片

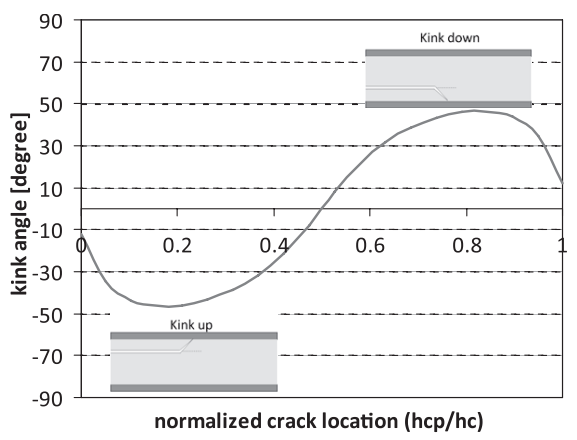

(b) T1 試験片

第 9 図 フォームコアサンドイッチ梁中のき裂位置とき裂偏向角の関係

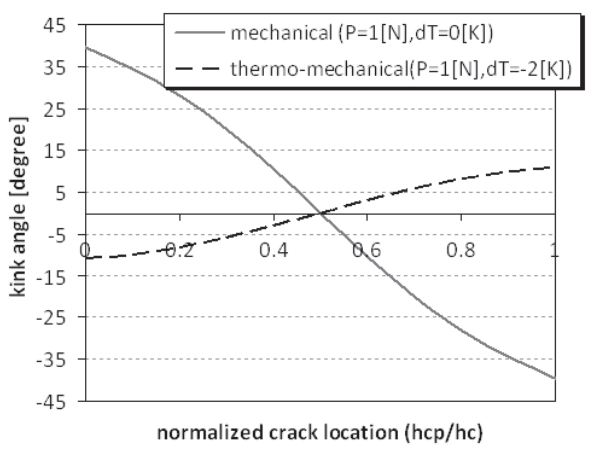

第 10 図 $\mathrm{CF}(4 \mathrm{~mm}) / \operatorname{core}(20 \mathrm{~mm}) / \mathrm{CF}(4 \mathrm{~mm})$ サンドイッチ梁中 のき裂位置とき裂偏向角の関係：熱応力の影響

ることを意味し，き裂はコアの中央部を安定的に進展しう ることを意味している。一方， $\mathrm{T} 1$ 試験片（第 9 図 (b)）で は，き裂位置がコア上部にある場合は上向きに偏向し，き 裂がコア下部にある場合は下向きに偏向するため，き裂が 表皮に貫入しないと仮定すると, 表皮/コア間を安定的に進 展しうることを意味している。この結果は文献 9) におけ る実験結果とよく一致する結果となっている，㛜密にいう と, き裂偏向後については本解析手法により解析を行うこ とはできないものの, 第 9 図のような, き裂位置を変化さ せたき裂偏向角予測により, フォームコアサンドイッチ梁 の安定的なき裂進展位置の予測が可能であると考えられる.

また, $\mathrm{CFRP}$ (厚さ $4 \mathrm{~mm}$ )/フォームコア (厚さ $20 \mathrm{~mm}$ )/ $\mathrm{CFRP}$ (厚さ $4 \mathrm{~mm}$ ) の DCB サンドイッチ梁について, き 裂長さが $50 \mathrm{~mm}$ の場合のき裂位置とき裂偏向角の関係に ついて，熱応力の影響を調査した。材料特性は第 2 表の值
を用い, 力学的荷重のみ $(P=1[\mathrm{~N}], \Delta T=0[\mathrm{~K}])$ の場 合と力学的荷重及び温度変化が作用する場合 $(P=1[\mathrm{~N}]$, $\Delta T=-2[\mathrm{~K}])$ について比較したものを第 10 図に示す。こ の計算例では, 力学的荷重のみの場合は, コア中央位置が 安定的なき裂進展位置であるが, 熱荷重も作用する場合に は，表皮/コア界面が安定位置であるということを示してい る。したがって, 熱荷重の考慮は安定的なき裂進展位置の 予測にとっても重要であると考えられる.

ここで示した安定的なき裂進展位置の予測は, DCB 試験 などの破壊勒性值試験の際に，界面破壊勒性值などの所定 の特性を取得可能な試験片設計に役立つことが期待される. 2 節のエネルギー解放率を算出する式とともに, フォーム コアサンドイッチ構造の開発や必要な破壊勒性試験の際に 有用と考えられる.

\section{4. 結 論}

本研究では, 航空機構造へのサンドイッチ構造の適用の 際に必要な破壊勒性試験に関する解析手法について, i) 熱残 留応力を考慮したサンドイッチ構造用破壊勒性試験に関す るエネルギー解放率の定式化, ii) フォームコアサンドイッ チ構造内のき裂偏向解析, について述べた.

高温で硬化させる航空機主構造用サンドイッチ構造にとっ て, 熱残留応力の影響は無視できず, 破壊勒性值試験におい ても破壊勒性值評価の際に考慮する必要があり，特にDCB 試験, $\mathrm{ENF}$ 試験, $\mathrm{MMB}$ 試験に関するエネルギー解放率 の式を導出した。 また, 特にフォームコアサンドイッチ構 造で問題となる, 破壊勒性值試験の際のき裂偏向に関して も, 導出した各モードのエネルギー解放率を利用した解析 手法を提示した。熱残留応力の影響を考慮・補正した破壊 勒性值算出や, 破壊勒性值試験片の安定的なき裂進展位置 予測などに有用と考えられる。本解析手法は，サンドイッ チ構造の評価試験や試験片設計に役立つことが期待される.

\section{参 考 文 献}

1) Herrmann, A., Zahlen, P. C. and Zuardy, I.: Sandwich Structures Technology in Commercial Aviation, Proceedings of the 7th International Conference on Sandwich Structures, Aalborg, Denmark, 2006, pp. 13-26.

2) Nokkentved, A., Lundsgaard-Larsen, C. and Berggreen, C.: Non-Uniform Compressive Strength of Debonded Sandwich Panels-I. Experimental Investigation, J. Sandwich Struct. Mater., 7 (2005), pp. 461-482.

3) Berggreen, C. and Simonsen, B. C.: Non-Uniform Compressive Strength of Debonded Sandwich Panels-II. Fracture Mechanics Investigation, J. Sandwich Struct. Mater., 7 (2005), pp. 483-517.

4) Shipsha, A., Burman, M. and Zenkert, D.: Interfacial Fatigue Crack Growth in Foam Core Sandwich Structures, Fatigue Fract. Eng. Mater., 22 (1999), pp. 123-131.

5) Grenestedt, J. L.: Development of a New Peel-Stopper for Sandwich Structures, Compos. Sci. Technol., 61 (2001), pp. $1555-1559$

6) Jakobsen, J., Bozhevolnaya, E. and Thomsen, O. T.: New Peel Stopper Concept for Sandwich Structures, Compos. Sci. Technol., 67 (2007), pp. 3378-3385.

7) Hirose, Y., Matsuda, H., Matsubara, G., Inamura, F. and Hojo, M.: Evaluation of a New Crack Suppression Method 
for Foam Core Sandwich Panel via Fracture Toughness Tests and Analysis under Mode-I Type Loading, J. Sandwich Struct. Mater., 11 (2009), pp. 451-470.

8) Aviles, F. and Carlsson, L. A.: Analysis of the Sandwich DCB Specimen for Debond Characterization, Eng. Fract. Mech., 75 (2008), pp. 153-168.

9) Carlsson, L. A., Matteson, R. C., Aviles, F. and Loup, D. C.: Crack Path in Foam Cored DCB Sandwich Fracture Specimens, Compos. Sci. Technol., 65 (2005), pp. 2612-2621.

10) Carlsson, L. A., Sendlein, L. S. and Merry, S. L.: Characterization of Face/Core Shear Fracture of Composite Sandwich Beams, J. Compos. Mater., 25 (1991), pp. 101-116.
11) Quispitua, A., Berggreen, C. and Carlsson, L. A.: On the Analysis of a Mixed Mode Bending Sandwich Specimen for Debond Fracture Characterization, Eng. Fract. Mech., 76 (2009), pp. 594-613.

12) Yokozeki, T.: Energy Release Rates of Bi-Material Interface Crack Including Residual Thermal Stresses: Application of Crack Tip Element Method, Eng. Fract. Mech., 77 (2010), pp. 84-93.

13) Erdogan, F. and Sih, G. C.: On the Crack Extension in Plates under Plane Loading and Transverse Shear, J. Basic Eng., 85 (1963), pp. 519-527. 